\title{
Concurrently Produce a Novel High-Potency Sweetener (Glycyrrhetic Acid 3-0-Mono- $\beta$-D- glucuronide) and Lignocellulolytic Enzymes using Plant Entophytic Chaetomium Globosum DX-THS3 by Solid-State Fermentation
}

\section{Boliang Gao}

Key Lab of Bioprocess Engineering of Jiangxi Province

\section{Yiwen Xiao}

College of life sciences, Jiangxi Science and Technology Normal University

\section{Qian Zhang}

College of life sciences, Jiangxi Science and Technology Normal University

Junru Sun

College of life sciences, Jiangxi Science and Technology Normal University

Zhibing Zhang

Key Laboratory of Protection and Utilization of Subtropic Plant Resources of Jiangxi Province

Du Zhu ( $\nabla$ zhudu12@163.com )

Jiangxi Science and Technology Normal University

\section{Research}

Keywords: Glycyrrhetic acid 3-0-mono- $\beta$-D-glucuronide, Chaetomium globosum DX-THS3, solid-state fermentation, lignocelluloses-degrading enzymes

Posted Date: June 2nd, 2021

DOI: https://doi.org/10.21203/rs.3.rs-563893/v1

License: (c) (i) This work is licensed under a Creative Commons Attribution 4.0 International License. Read Full License 


\section{Abstract}

Licorice straw was used for the first time as a medium for glycyrrhetic acid 3-0-mono- $\beta$-D-glucuronide (GAMG) and lignocellulosic enzyme production via solid-state fermentation (SSF) of endophytic fungus Chaetomium globosum DX-THS3. Under optimal fermentation conditions, the percent conversion of glycyrrhizin reached $90 \%$ in 15 days, whereas the control needed 35 days to achieve the same result. The productivity of optimization $\left(P=2.1 \mathrm{mg}^{\circ} \mathrm{g}^{-1} \cdot \mathrm{day}^{-1}\right)$ was 2.33 -fold that of non-optimization $(P=0.9 \mathrm{mg} \cdot \mathrm{g}$ ${ }^{1} \cdot$ day $\left.^{-1}\right)$. Meanwhile, high activities of filter paper enzyme (FPase) $(234.6 \mathrm{U} / \mathrm{g})$, carboxymethyl cellulase (CMCase) $(29.25 \mathrm{U} / \mathrm{g})$, xylanase $(72.52 \mathrm{U} / \mathrm{g})$, and $\beta$-glucuronidase activity $(264.17 \mathrm{U} / \mathrm{g})$ were obtained faster than those in the control during SSF. Our study provides a novel and efficient strategy for GAMG production and indicates $C$. globosum DX-THS3 as a potential producer of lignocellulolytic enzymes.

\section{Introduction}

Glycyrrhizin (GL) is a major bioactive component of industrial crop Glycyrrhiza (Pandey \& Ayangla, 2017) with numerous valuable physiological properties, including antioxidative (Michaelis et al., 2011), antiviral (Ito et al., 1988), anticancer (Huang et al., 2016), and anti-inflammatory (Wang et al., 2015a) action. GL can efficiently inhibit the coronavirus disease (COVID-19) virus, and it is commonly considered a potential chemical for the cure of COVID-19 (Bailly \& Gérard Vergoten, 2020; Murck, 2020). However, GL has low absorption and strong adverse effects in humans and animals (Akao, 2000; Wang et al., 2013). GL can be transformed into glycyrrhetic acid 3-0-mono- $\beta$-D-glucuronide (GAMG), which possesses improved biological activities and safety and higher solubility, by hydrolysis of one of the terminal glucuronic acids of GL (Lin et al., 2009; Li et al., 2017). Furthermore, GAMG is about 5 and 1000 times sweeter than GL and sucrose (Mizutani et al., 1994), respectively, and tastes better (less aftertaste) than GL. Therefore, GAMG has valuable application, especially in the food industry. However, efficient approaches for large-scale GAMG production are unavailable thus far.

GAMG can be produced by chemical synthesis and biotransformation. However, chemical approaches generally present several disadvantages, including the requirement of strong and harsh conditions, ineffective costs, poor selectivity, and environmental pollution (Brieskorn \& Lang, 1978). Compared with chemical approaches, the biosynthesis of GAMG significantly has more potential and advantages because of its excellent substrate selectivity, high yields, mild reaction conditions, and eco-friendly status. The efficient biosynthesis of GAMG involves the use of $\beta$-glucuronidase (GUS) (Zou et al., 2013; Xu et al., 2018; Wang et al., 2013; Park et al., 2005). At present, GUSs are mainly screened from microorganisms (Zou et al., 2013; Xu et al., 2018; Wang et al., 2013; Park et al., 2005). However, most of reported GUSs exhibit a low hydrolytic selectivity and cause further transformation of GAMG to GA. On the other hand, GUS is generally prepared by microorganic fermentation. The isolation of GUS for biosynthesis of GAMG has several challenges, such as complicated processes and harsh cultivation conditions. Therefore, an efficient, simple, and feasible approach for the production of GAMG must be developed. 
In general, most enzymes are produced by microorganic submerged fermentation (SF). GUS can also be produced by SF of Aspergillus terreus Li-20 (Xu et al., 2018), Streptococcus LJ-22 (Park et al., 2005), and Penicillium purpurogenum Li-3 (Zou et al., 2013). However, their applications in the manufacturing industry have been met with several processing challenges, including low productivity, especially in terms of ineffective costs of the mass production of enzymes. Compared with SF, solid-state fermentation (SSF) can offer several advantages, including low equipment requirements, simple culture processing, and the use of widely available and inexpensive lignocellulosic residues (usually crop straws and wastes) as substrates (Pandey, 2003). Therefore, SSF is very suitable to produce highly bioactive products, such as enzymes. Thus, the utilization of SSF for large-scale production of GAMG should be considered. However, to date, the use of SSF to produce GAMG has not been investigated.

Endophytic fungi are an ecological group of fungi that is present in living plant tissues without initiating any external symptoms. Endophytic fungi have attracted research attention because they can secrete a number of secondary metabolites, including bioactive chemicals (Suryanarayanan et al., 2012). In addition, endophytic fungi can be utilized as plant material, for example, crop straw, for use as a medium for SSF to produce valuable products, such as bioactive chemicals and enzymes (Prajapati et al., 2018; Natália et al., 2018; Deswal et al., 2011). In our previous study, an endophytic fungus Chaetomium globosum DX-THS3 was isolated from Dongxiang wild rice (Oryza rufipogon Griff.) (Wang et al., 2015b). Furthermore, a GUS with specificity and highly transformable GL to generate GAMG was screened from $C$. globosum DX-THS3 (Zhang et al., 2020), and genome analysis showed abundant genes coding lignocellulose-degrading enzymes harbored in the C. globosum DX-THS3 genome (unpublished). Therefore, in this study, C. globosum DX-THS3 was utilized with licorice straw as a medium for SSF. We aimed to i.) investigate the feasibility of GAMG production by $C$. globosum DX-THS3 via SSF and provide an efficient strategy for large-scale production of GAMG; ii.) analyze the lignocellulose-degrading enzymes, such as carboxymethyl cellulase (CMCase), FPase, xylanase, and GUS, during SSF to simultaneously obtain high-activity enzymes and demonstrate $C$. globosum DX-THS3 as a potential candidate for producing lignocellulose-degrading enzymes.

\section{Material And Methods}

\subsection{Chemicals and strains}

Licorice straw was purchased from Inner Mongolia, China. Standard GL and GA samples (purity $\geq 98 \%$ ) were purchased from Sigma Chemical Co. (USA). Standard GAMG (purity $>98 \%$ ) was prepared and identified via carbon-13 nuclear magnetic resonance in our laboratory. Other chemicals and solvents (analytical grade) were purchased from Xilong Scientific Co., Ltd. (China). The endophytic fungal strain $C$. globosum DX-THS3 (CCTCC M2016005) was isolated from healthy Dongxiang wild rice in a nature reserve in Dongxiang county, Jiangxi province, China in our previous work and collected by Jiangxi Normal University, Nanchang, China.

\subsection{Production of GAMG by SSF}


Licorice straw was dried for $24 \mathrm{~h}$ in a drying oven and then crushed to obtain $<3 \mathrm{~mm}$ grain diameter. $C$. globosum DX-THS3 was cultured in a $500 \mathrm{~mL}$ flask with $200 \mathrm{~mL}$ seed culture medium (potato dextrose broth (PDB)) at $28^{\circ} \mathrm{C}$ on a rotary shaker at $150 \mathrm{rpm}$ for seed broth preparation. Then, $2 \mathrm{~mL}$ seed broth was cultured in $15 \mathrm{~g}$ sterile licorice straw grain, which was pre-added with $5 \mathrm{~mL}$ sterile water at $28^{\circ} \mathrm{C}$ for the production of GAMG. After 20 days of culture, $2 \mathrm{~g}$ culture medium was ground and added to $100 \mathrm{~mL}$ water for the determination of GAMG using thin layer chromatography (TLC) and ultraperformance liquid chromatography (UPLC, Waters, USA).

\subsection{Optimization of SSF conditions}

Strain DX-THS3 was cultivated in different fermentation conditions to detect the GUS activity and yield of GAMG for optimization of fermentation conditions. First, $2 \mathrm{~mL}$ seed broth was cultivated in licorice straw of different particle sizes (grain diameter: $0-0.25,0.26-0.85$, and $0.86-3.0 \mathrm{~mm}$ ) at $28^{\circ} \mathrm{C}$. Then, the GUS activity and yield of GAMG were analyzed after culturing for 20 days. Then, strain DX-THS3 was grown on licorice straw at $24^{\circ} \mathrm{C}, 28^{\circ} \mathrm{C}$, and $33^{\circ} \mathrm{C}$ for the analysis of GUS activity and yield of GAMG after 20 days. For optimization of seed age, different seed broths cultivated in PDB medium for $48,60,72,84,96$, 108,120 , and $132 \mathrm{~h}$ were grown on licorice straw at $28^{\circ} \mathrm{C}$ to analyze the GUS activity and yield of GAMA after culturing for 20 days. To optimize the inoculum of seed broth, different volumes of seed broths $(15 \%, 20 \%, 25 \%, 30 \%, 35 \%$, and $40 \%, v / w)$ in licorice straw at $28{ }^{\circ} \mathrm{C}$ to analyze the GUS activity and yield of GAMA after culturing for 20 days. To optimize the water content of licorice straw, strain DX-THS3 were cultured on licorice straw containing different water contents (straw: water $=1: 2,1: 2.5,1: 3,1: 3.5, \mathrm{~m} / \mathrm{m}$ ) at $28^{\circ} \mathrm{C}$ to analyze the GUS activity and yield of GAMA after 20 days of culture. Finally, glucose, fructose, sucrose, lactose, $\mathrm{NH}_{4} \mathrm{NO}_{3}$, peptone, yeast powder, and yeast extract were added to the licorice straw for optimization of carbon and nitrogen sources. All cultivations were performed in triplicate.

\subsection{Determination of lignocellulosic enzyme activities}

Two grams of solid-state medium was sampled, ground by liquid nitrogen, and then dissolved in $15 \mathrm{~mL}$ sodium acetate $\left(\mathrm{pH}\right.$ 5.0). The suspension was centrifuged at $4{ }^{\circ} \mathrm{C}$ and $10,000 \times \mathrm{g}$, and the supernatant was collected for the preparation of crude enzymes. Endoglucanase activity (CMCase) was assayed in a reaction containing $1 \mathrm{~mL}$ carboxymethyl cellulose solution ( $2 \%$ sodium acetate, $\mathrm{pH} 5.0, \mathrm{v} / \mathrm{v}$ ) and $1 \mathrm{~mL}$ crude enzymatic solution. After incubation for $30 \mathrm{~min}$ at $50{ }^{\circ} \mathrm{C}$, reducing sugar was detected by 3,5dinitrosalicylic acid (DNS) method (Zhao et al., 2008) with glucose as the standard. FPase activity was analyzed using Whatman No. 1 filter paper $\left(1 \times 6 \mathrm{~cm}^{2}, 50 \mathrm{mg}\right)$ in a $2 \mathrm{~mL}$ total volume reaction containing $1 \mathrm{~mL}$ crude enzymatic solution and $1 \mathrm{~mL}$ sodium acetate $(\mathrm{pH} 5.0)$ for $60 \mathrm{~min}$ at $50^{\circ} \mathrm{C}$. Then, the reducing sugar was detected by DNS method. One unit $(U)$ of CMCase and FPase activity was defined as the amount of enzyme that released $1 \mu \mathrm{mol}$ glucose equivalent per minute. Xylanase activity was assayed in a solution containing $1 \%(\mathrm{w} / \mathrm{v})$ xylan $(1 \mathrm{~mL})$ in $50 \mathrm{mM}$ solidum acetate buffer $(\mathrm{pH} 5.0)$ and appropriately diluted crude enzyme $(1 \mathrm{~mL})$. After $10 \mathrm{~min}$ incubation at $50{ }^{\circ} \mathrm{C}$, reducing sugar was detected by DNS method. One unit $(U)$ of xylanase activity was defined as the amount of enzyme that released $1 \mu \mathrm{mol}$ xylose equivalents per minute. $\beta$-Glucosidase activity was detected based on the release of $\rho$-nitrophenol ( $\rho N P$ ) from the $\rho$-nitrophenyl- $\beta$-d-glucopyranoside ( $\rho N P G$ ) substrate, and the absorbance was read at 430 
$\mathrm{nm}$. The assayed reaction containing $1 \mathrm{~mL}$ crude enzyme and $1 \mathrm{~mL} \rho \mathrm{NPG}(5 \mathrm{mM})$ was incubated for 10 min at $50{ }^{\circ} \mathrm{C}$ and then disrupted by $3 \mathrm{~mL} 0.5 \mathrm{M}$ sodium carbonate. One unit (U) of $\beta$-glucosidase activity was defined as the amount of enzyme that released $1 \mu \mathrm{mol} \rho \mathrm{NP}$ equivalent per minute.

\subsection{Determination of total and reducing sugars}

Two grams of solid-state medium was sampled, ground by liquid nitrogen, and then dissolved in $15 \mathrm{~mL}$ water. The suspension was centrifuged at $4{ }^{\circ} \mathrm{C}$ and $10,000 \times \mathrm{g}$, and the supernatant was collected for sample preparation. The total sugar of solid-state medium was determined in accordance with the phenol sulfuric acid method (Masuko et al., 2005), whereas reducing sugars were quantified by the DNS method.

\subsection{Determination of GUS activity}

Two grams of solid-state medium was sampled, ground by liquid nitrogen, and then dissolved in $15 \mathrm{~mL}$ sodium acetate $\left(\mathrm{pH}\right.$ 6.0). The suspension was centrifuged at $4{ }^{\circ} \mathrm{C}$ and $10,000 \times \mathrm{g}$, and the supernatant was collected for the preparation of crude enzymes. GUS activity was assayed by the reaction containing $200 \mu \mathrm{L}$ crude enzymatic solution and $800 \mu \mathrm{L} \mathrm{GL}$ solution $(2 \mathrm{~g} / \mathrm{L})$. Then, the reaction was incubated at 45 ${ }^{\circ} \mathrm{C}$ for $1 \mathrm{~h}$ and disrupted by boiling water and analyzed by UPLC. One unit (U) of GUS activity was defined as the amount of enzyme that released $0.1 \mu \mathrm{mol}$ GAMG equivalent per minute.

\subsection{Determination of product and yield}

Two grams of solid-state medium was sampled, ground by liquid nitrogen, and dissolved in $15 \mathrm{~mL}$ water. The suspension was centrifuged at $4{ }^{\circ} \mathrm{C}$ and $10000 \times \mathrm{g}$, and the supernatant was collected and measured with a metered volume of $100 \mathrm{~mL}$ for sample preparation. Then, GAMG and GA were determined by UPLC. UPLC analysis was performed on an ACQUITY UPLC (Waters, USA) instrument using a C18 column ( $4.6 \mathrm{~mm} \times 250 \mathrm{~mm}, 5 \mu \mathrm{m}$, InertSustain, Japan) and UV detector, at the detection wavelength of $254 \mathrm{~nm}$, injection volume of $10 \mu \mathrm{L}$, flow rate of $1.0 \mathrm{~mL} / \mathrm{min}$, and mobile phase $\mathrm{MeOH}-0.5 \%$ acetate $(80: 20)$.

The concentration of GAMG in samples (defined as $C_{\mathrm{s}}(\mathrm{mg} / \mathrm{mL})$ ) was determined by UPLC with a standard curve. The concentration of GAMG per gram of solid-state medium (defined as $\mathrm{C}_{\mathrm{ssf}}(\mathrm{mg} / \mathrm{g})$ ) was detected by $C_{s s f}=\left(C_{s} \times 100\right) / 2$. The production of GAMG by SSF (defined as $Y(m g / g)$ ) was quantified by $\mathrm{Y}=\mathrm{C}_{\mathrm{ssf}} \times \mathrm{m} / \mathrm{m}_{0}$, whereas $\mathrm{m}_{0}$ is the weight $(\mathrm{g})$ of initial substrate (licorice straw, $15 \mathrm{~g}$ in this study), and $\mathrm{m}$ is the weight $(\mathrm{g})$ of solid-state medium after fermentation. The productivity of GAMG by SSF (defined as $\mathrm{P}(\mathrm{mg} / \mathrm{g} /$ day $))$ was shown by $\mathrm{P}=\mathrm{Y} /$ day.

\section{Results And Discussion}

\subsection{Production of GAMG by C. globosum DX-THS3 using licorice straw as substrate}


C. globosum DX-THS3 is an endophytic fungus, and it was isolated from Dongxiang wild rice in our previous work (Wang et al., 2015b). In this study, strain DX-THS3 can utilize licorice straw as a substrate for producing GAMG. Strain DX-THS3 was cultivated in licorice straw to produce GAMG by SSF (Fig. 1A). After 20 days of cultivation, $C$. globosum DX-THS3 covered almost all of the licorice straw (Fig. 1A, right). Solid-state medium was sampled, and the product was analyzed by TLC to detect the GAMG. As shown in Fig. 1B, only GL was detected in the licorice straw (b), but after 20 days of fermentation, considerable GAMG was detected using TLC (c). UPLC was performed for identification and further confirmation of these products. Our results confirmed that GAMG was the product in SSF (Fig. 1C). Thus, our results show that GL of licorice straw can be bio-transformed to produce GAMG using licorice straw as a substrate by $C$. globosum DX-THS3.

GAMG is an innovative functional sweetener with higher sweetness and stronger pharmacological activity than GL (Lin et al., 2009; Li et al., 2017; Mizutani et al., 1994). Biocatalysis of GAMG is a more environment-friendly and efficient than the chemical method (Brieskorn \& Lang, 1978). To date, several microorganisms (mainly fungi) are screened for GL transformation to produce GAMG. However, a limited number of microorganisms have a GL-hydrolyzing ability. Especially, microorganisms that can selectively transform GL to generate GAMG are rarely found. The previously reported microorganisms with GLhydrolyzing ability mainly include fungi, such as the filamentous fungus $P$. purpurogenum Li-3 (Zou et al., 2013) and Talaromyces pinophilus Li-93 (Xu et al., 2018), and screened from soil. However, the poor substrate specificity and low efficiency are the main disadvantages that limit the further application of these reported fungi. On the other hand, the production of GAMG by microorganic enzymes (GUS) involve tedious steps, including strain cultivation, fermentation, enzyme extraction, enzymatic reaction, and product separation, that seriously limit the application of microorganic enzymes in industries. Thus, screening microorganism from other sources and a novel strategy for high-efficient utilization of microorganic enzymes should be suggested. In this study, an endophytic fungi $C$. globosum DX-THS3 selectively and efficiently transformed GL to produce GAMG when using licorice straw as substrate in SSF. To our knowledge, this work is the first to report the GL production by SSF using endophytic fungi. This research also contributes to the application of endophytic fungi as potential industrial strains in food, biopharmaceutical, and biotechnological industries.

3.2 Optimization of SSF conditions for GAMG production by C. globosum DX-THS3 using licorice straw as substrate

We optimized the SSF conditions for GAMG production by $C$. globosum DX-THS3 using licorice straw as substrate in the present study. The particle size of the substrate is one of the key factors in SSF. Thus, we first investigated the effect of particle size of licorice straw on GAMG production by $C$. globosum DXTHS3. As shown in Fig. 2A, $4.56 \mathrm{mg} / \mathrm{g}$ (yield, Y) GAMG was produced by C. globosum DX-THS3 when using small-sized licorice straw $(0-0.25 \mathrm{~mm})$ as the substrate after 20 days of fermentation; $10.47 \mathrm{mg} / \mathrm{g}$ (Y) of GAMG was obtained using a medium particle size $(0.26-0.85 \mathrm{~mm})$ of licorice straw after 20 days of fermentation, and $10.35 \mathrm{mg} / \mathrm{g}(\mathrm{Y})$ GAMG was detected using licorice straw with a large particle size $(0.86-3.0 \mathrm{~mm})$. Our results show that the medium particle size of licorice straw was better than the other 
particle sizes for the production of GAMG by C. globosum DX-THS3. Furthermore, other fermentation conditions, including temperature, seed age, inoculum size, and solid-liquid ratio (substrate:water, $\mathrm{m} / \mathrm{v}$ ), were optimized. Our results show that $28{ }^{\circ} \mathrm{C}(Y=10.47 \mathrm{mg} / \mathrm{g}$, Fig. 2B), $96 \mathrm{~h}$ seed age $(Y=13.46 \mathrm{mg} / \mathrm{g}$, Fig. 2C), $20 \%$ inoculum size $(Y=19.78 \mathrm{mg} / \mathrm{g}, \mathrm{v} / \mathrm{w}$, Fig. $2 D)$, and $1: 3$ solid-liquid ratio $(Y=11.75 \mathrm{mg} / \mathrm{g}$, Fig. 2E) were the optimal conditions for the production of GAMG by SSF using C. globosum DX-THS3. These optimal SSF conditions $\left(0.26-0.85 \mathrm{~mm}\right.$ licorice straw, $28^{\circ} \mathrm{C}, 96 \mathrm{~h}$ seed age, $20 \%$ inoculum size, and 1:3 solid-liquid ratio) were confirmed.

The fermentation conditions can markedly influence the products (not only the kinds but also the yields) when fermenting using microorganisms (Singh et al., 2017). Similar to liquid fermentation, temperature and seed age should be considered when using microorganisms (most of which belong to fungi) for SSF. However, special fermentation conditions, such as the particle size of substrate and water content, should be primarily considered. In general, oversized or extremely small particle size of substrate is unsuitable for SSF using fungi. Oversized particles can affect substrate release, especially that of lignocellulose, and significantly reduce the contact area of fungi with the substrate (Pandey, 2003). On the other hand, an extremely small particle size can influence fungal growth (Pandey, 2003). Water and substrate powder will mix to form a tight bulk or pellet, which not only significantly reduces oxygen transfer but also obstructs in-depth growth of fungal mycelium. In this study, the particle size of licorice straw was first optimized, and our results showed a suitable particle size of $0.26-0.85 \mathrm{~mm}$ (Fig. 2A) for the production of GAMG by SSF using C. globosum DX-THS3. Water content of substrate is another important factor for SSF by fungi. Low water content is a poor condition for fungal growth. However, a high water content can also inhibit fungal growth, that is, when oxygen transfer is obstructed by high water content of substrate. Thus, suitable water content is required in SSF, and a similar result was obtained in our study (Fig. 2E).

\subsection{High activity of lignocellulosic enzymes during the degradation of licorice straw by C. globosum DX-THS3}

C. globosum DX-THS3 was first cultured in pre-treated licorice straw under the above fermentation conditions to further investigate the feasibility of this novel strategy for GAMG production. C. globosum DX-THS3 mycelium was grown slowly in the early stage of fermentation (0-6 days). Then, the growth of C. globosum DX-THS3 gradually hastened in the middle stage of fermentation (7-12 days), and the mycelium covered the licorice straw after 20 days of fermentation. Then, deep fermentation was performed (Fig. 3A). The yields of GAMG by $C$. globosum DX-THS3 using licorice straw as substrate were analyzed during SSF to detect the production of GAMG by C. globosum DX-THS3. The production of GAMG was extremely low in the early and middle stages (0-18 days) of SFF (Fig. 3B). Until 18 days of fermentation, the yield of GAMG significantly increased. Our results demonstrate that the yield of GAMG reached $13.73 \mathrm{mg} / \mathrm{g}$ after 20 days, and the percent conversion of $\mathrm{GL}$ reached $90 \%(\mathrm{Y}=31.5 \mathrm{mg} / \mathrm{g})$ after about 33 days of SSF (Fig. 3B). Furthermore, the total and reducing sugars were detected during SSF to investigate the utilization of carbon source by $C$. globosum DX-THS3. The total sugar of substrate continuously decreased during 0-30 days of SSF and stabilized afterward (Fig. 3C). Thus, the growth period of C. globosum DX-THS3 was mainly at 0-30 days of SSF. The reducing sugar increased rapidly 
at the early stage of SSF ( $0-7$ days), and the highest concentration was detected at 7 days. Then, the reducing sugar was largely utilized by $C$. globosum DX-THS3 (Fig. 3C). The reducing sugar lowly increased again at the middle stage of SSF (20-22 days, Fig. 3C). The corresponding enzymatic activities, including those of CMCase, FPase, $\beta$-glucosidase, and xylanase, were analyzed during SSF to investigate the variation in reducing sugar during SSF by $C$. globosum DX-THS3. Lignocellulosic enzymatic activities were observed at the early stage of SSF, and the highest activities of CMCase (29.25 $\mathrm{U} / \mathrm{g})$, FPase $(232.5 \mathrm{U} / \mathrm{g})$, and xylanase $(72.52 \mathrm{U} / \mathrm{g})$ were detected at 10,7 , and 7 days of SSF, respectively (Table 1 and Fig. 3D). Meanwhile, our results showed rare $\beta$-glucosidase activity during SSF of $C$. globosum DX-THS3, whereas $6.42 \mathrm{U} / \mathrm{g}$ enzymatic activity was detected at 22 days of SSF.

Table 1

Analysis of lignocellulose-degrading enzymatic activities and production of GAMG under optimal fermentation conditions.

\begin{tabular}{|c|c|c|c|}
\hline & Enzymes & Max enzymatic activity (U/g) & Days (d) \\
\hline \multirow[t]{5}{*}{ Non-optimization } & CMCase & $29.25 \pm 1.05$ & 10 \\
\hline & FPase & $232.5 \pm 30$ & 7 \\
\hline & $\beta$-glucosidase & $6.42 \pm 0.5175$ & 22 \\
\hline & Xylanase & $72.52 \pm 4.00$ & 7 \\
\hline & GUSase & $264 \pm 12$ & 20 \\
\hline \multirow[t]{5}{*}{ Optimization } & CMCase & $33.67 \pm 2.48$ & 5 \\
\hline & FPase & $245.8 \pm 13.4$ & 3 \\
\hline & $\beta$-glucosidase & $5.78 \pm 0.69$ & 20 \\
\hline & Xylanase & $83.44 \pm 3.76$ & 3 \\
\hline & GUSase & $271.42 \pm 6.54$ & 10 \\
\hline
\end{tabular}

Biotransformation has more potential than chemical approaches because of its high yield, high selectivity, and environmental compatibility. Compared with liquid fermentation, SSF has many advantages, including low cost and simple processing, for the production of certain compounds. Meanwhile, excellent lignocellulose-degrading activities for utilization of complex substrates (usually crop straw) by microorganisms are needed. Thus, fungi that harbor rich genes coding lignocellulosic enzymes and excellent lignocellulose-degrading activities are usually used in SSF for the production of certain compounds in most previous reports; such fungi include Ceratocystis paradoxa TT1 (Nutongkaew et al., 2019) and Trichoderma koningiopsis TM3 (Nutongkaew et al., 2019) for the degradation of oil palm trunk to produce reducing sugar. Trichoderma asperellum UC1 (Ezeilo et al., 2019) utilizes raw oil palm frond leaves to produce cellulase and xylanase. Similarly, high lignocellulose-degrading enzymatic activities were found during SSF (Table 1 and Fig. 3D) using C. globosum DX-THS3 (Table 2). The 234.6 $\mathrm{U} / \mathrm{g}$ FPase activity was detected during SSF, and this value is substantially higher than the other reported 
FPase activities in SSF using fungi. T. asperellum UC1 (Ezeilo et al., 2019) showed a relative high FPase $(26.02 \mathrm{U} / \mathrm{g})$ activity when using oil palm frond leaves as substrate for SSF, and most FPase activity was detected at 0.09-5 U/g (Table 2). High FPase activity indicates that complex cellulose can be degraded to generate easily hydrolyzed cello-oligomers, which are then further utilized by fungi. Furthermore, compared with the results of other studies, lignocellulose-degrading enzymes, including CMCase, xylanase, and $\beta$-glucosidase, from $C$. globosum DX-THS3 during SSF exhibited relative better enzymatic activities (Tables 1 and 2). Thus, high FPase activity and relative excellent CMCase, xylanase, and $\beta$ glucosidase activities were detected during SSF by $C$. globosum DX-THS3, demonstrating their wide application in SSF. Our results also strongly consider $C$. globosum DX-THS3 as a potential producer for producing lignocellulose-degrading enzymes. 
Table 2

Comparison of CMCase, FPase, $\beta$-glucosidase, xylanase, and GUS activities by $C$. globosum DX-THS3 and other fungi under SSF.

\begin{tabular}{|c|c|c|c|c|}
\hline Enzymes & Strains & $\begin{array}{l}\text { Enzymatic } \\
\text { activity }(\mathrm{U} / \mathrm{g})\end{array}$ & Substrate & Reference \\
\hline \multirow[t]{10}{*}{ CMCase } & T. viridae PAJ 01 & 64.56 & $\begin{array}{l}\text { Sugarcane } \\
\text { bagasse/wheat bran }\end{array}$ & $\begin{array}{l}\text { N.P. Marques } \\
\text { et al. }\end{array}$ \\
\hline & $\begin{array}{l}\text { Chaetomium sp. } \\
\text { TCF } 01\end{array}$ & 12.13 & $\begin{array}{l}\text { Sugarcane } \\
\text { bagasse/wheat bran }\end{array}$ & $\begin{array}{l}\text { N.P. Marques } \\
\text { et al. }\end{array}$ \\
\hline & A. fumigatus & 16.90 & Wheat straw & A. Shenef et al. \\
\hline & Botryosphaeria sp. & 8.13 & Empty fruit bunch & $\begin{array}{l}\text { E. K. Bahrin et } \\
\text { al. }\end{array}$ \\
\hline & $\begin{array}{l}\text { Fomitopsis sp. } \\
\text { RCK2010 }\end{array}$ & 71.70 & Wheat bran & $\begin{array}{l}\text { D. Deswal et } \\
\text { al. }\end{array}$ \\
\hline & $\begin{array}{l}\text { Hypocreanigricans } \\
\text { TT2 }\end{array}$ & 6.10 & Oil palm trunk & $\begin{array}{l}\text { Nutongkaew T. } \\
\text { et al. }\end{array}$ \\
\hline & $\begin{array}{l}\text { T. koningiopsis } \\
\text { TM3 }\end{array}$ & 7.13 & Oil palm trunk & $\begin{array}{l}\text { Nutongkaew T. } \\
\text { et al. }\end{array}$ \\
\hline & $\begin{array}{l}\text { T. asperellum } \\
\text { RCK2011 }\end{array}$ & 10.25 & Wheat bran & $\begin{array}{l}\text { Raghuwanshi } \\
\text { et al. }\end{array}$ \\
\hline & T. asperellum UC1 & 136.12 & Oil palm frond leaves & $\begin{array}{l}\text { Ezeilo, U. R. et } \\
\text { al. }\end{array}$ \\
\hline & $\begin{array}{l}\text { C. globosum DX- } \\
\text { THS3 }\end{array}$ & 29.25 & Licorice straw & This work \\
\hline \multirow[t]{6}{*}{ FPase } & $\begin{array}{l}\text { Chaetomium sp. } \\
\text { TCF } 01\end{array}$ & 0.09 & $\begin{array}{l}\text { Sugarcane } \\
\text { bagasse/wheat bran }\end{array}$ & $\begin{array}{l}\text { N.P. Marques } \\
\text { et al. }\end{array}$ \\
\hline & A. fumigates & 0.98 & Wheat straw & $\begin{array}{l}\text { Sherief, A. A. et } \\
\text { al. }\end{array}$ \\
\hline & $\begin{array}{l}\text { A. tubingensis } \\
\text { NKBP- } 55\end{array}$ & 3.8 & Copra meal & Prajapati et al. \\
\hline & Botryosphaeria sp. & 3.30 & Empty fruit bunch & $\begin{array}{l}\text { Bahrin E.K. et } \\
\text { al. }\end{array}$ \\
\hline & C. paradoxa TT1 & 1.64 & Oil palm trunk & $\begin{array}{l}\text { Nutongkaew T. } \\
\text { et al. }\end{array}$ \\
\hline & $\begin{array}{l}\text { Fomitopsis sp. } \\
\text { RCK2010 }\end{array}$ & 3.50 & Wheat bran & $\begin{array}{l}\text { Deswal, D. et } \\
\text { al. }\end{array}$ \\
\hline
\end{tabular}

a: GUS proteins were purified and enriched, and enzymatic activities were detected;

b: GUS activity of solid-state medium was detected. 


\begin{tabular}{|c|c|c|c|c|}
\hline \multirow[t]{5}{*}{ Enzymes } & Strains & $\begin{array}{l}\text { Enzymatic } \\
\text { activity (U/g) }\end{array}$ & Substrate & Reference \\
\hline & T. auraticus & 4.40 & Wheat straw & $\begin{array}{l}\text { Kalogeris E. et } \\
\text { al. }\end{array}$ \\
\hline & $\begin{array}{l}\text { T. asperellum MR } \\
1\end{array}$ & 0.72 & $\begin{array}{l}\text { Pressed oil palm petiole } \\
\text { fiber }\end{array}$ & $\begin{array}{l}\text { Ikubar M.R.M. } \\
\text { et al. }\end{array}$ \\
\hline & T. asperellumUC1 & 26.02 & Oil palm frond leaves & $\begin{array}{l}\text { Ezeilo, U. R. et } \\
\text { al. }\end{array}$ \\
\hline & $\begin{array}{l}\text { C. globosum DX- } \\
\text { THS3 }\end{array}$ & 234.6 & Licorice straw & This work \\
\hline \multirow[t]{6}{*}{$\begin{array}{l}\beta \text { - } \\
\text { glucosidase }\end{array}$} & $\begin{array}{l}\text { Chaetomium sp. } \\
\text { TCF } 01\end{array}$ & 3.81 & $\begin{array}{l}\text { Sugarcane } \\
\text { bagasse/wheat bran }\end{array}$ & $\begin{array}{l}\text { N.P. Marques } \\
\text { et al. }\end{array}$ \\
\hline & $\begin{array}{l}\text { A. tubingensis } \\
\text { NKBP- } 55\end{array}$ & 71.0 & Copra meal & Prajapati et al. \\
\hline & I. obliquus & 2.58 & Wheat bran & Xu X. et al. \\
\hline & $\begin{array}{l}\text { T. asperellum MR } \\
1\end{array}$ & 0.43 & $\begin{array}{l}\text { Pressed oil palm petiole } \\
\text { fiber }\end{array}$ & $\begin{array}{l}\text { Ikubar M.R.M. } \\
\text { et al. }\end{array}$ \\
\hline & T. asperellum UC1 & 130.09 & Oil palm frond leaves & $\begin{array}{l}\text { Ezeilo, U. R. et } \\
\text { al. }\end{array}$ \\
\hline & $\begin{array}{l}\text { C. globosum DX- } \\
\text { THS3 }\end{array}$ & 6.42 & Licorice straw & This work \\
\hline \multirow[t]{8}{*}{ Xylanase } & T. viridae PAJ 01 & 351.74 & $\begin{array}{l}\text { Sugarcane } \\
\text { bagasse/wheat bran }\end{array}$ & $\begin{array}{l}\text { N.P. Marques } \\
\text { et al. }\end{array}$ \\
\hline & $\begin{array}{l}\text { Chaetomium sp. } \\
\text { TCF } 01\end{array}$ & 39.75 & $\begin{array}{l}\text { Sugarcane } \\
\text { bagasse/wheat bran }\end{array}$ & $\begin{array}{l}\text { N.P. Marques } \\
\text { et al. }\end{array}$ \\
\hline & A.niger USM Al 1 & 35.00 & Palm kernel cake & $\begin{array}{l}\text { Kheng P.P. et } \\
\text { al. }\end{array}$ \\
\hline & A. fumigatus & 56.40 & Wheat straw & Sherief A. et al. \\
\hline & $\begin{array}{l}\text { A. tubingensis } \\
\text { TSIP9 }\end{array}$ & 59.30 & Empty fruit bunch & Kitcha S. et al. \\
\hline & $\begin{array}{l}\text { A.tubingensis } \\
\text { NKBP-55 }\end{array}$ & 167 & Copra meal & Prajapati et al. \\
\hline & $\begin{array}{l}\text { T. koningiopsis } \\
\text { TM3 }\end{array}$ & 56.46 & Oil palm trunk & $\begin{array}{l}\text { Nutongkaew T. } \\
\text { et al. }\end{array}$ \\
\hline & $\begin{array}{l}\text { T. asperellum MR } \\
1\end{array}$ & 5.69 & $\begin{array}{l}\text { Pressed oil palm petiole } \\
\text { fiber }\end{array}$ & $\begin{array}{l}\text { lkubar M.R.M. } \\
\text { et al. }\end{array}$ \\
\hline \multicolumn{5}{|c|}{ a: GUS proteins were purified and enriched, and enzymatic activities were detected; } \\
\hline & & $\mathrm{cdo}$ & & \\
\hline
\end{tabular}




\begin{tabular}{|c|c|c|c|c|}
\hline \multirow[t]{3}{*}{ Enzymes } & Strains & $\begin{array}{l}\text { Enzymatic } \\
\text { activity (U/g) }\end{array}$ & Substrate & Reference \\
\hline & T. asperellum UC1 & 255.01 & Oil palm frond leaves & $\begin{array}{l}\text { Ezeilo, U. R. et } \\
\text { al. }\end{array}$ \\
\hline & $\begin{array}{l}\text { C. globosum DX- } \\
\text { THS3 }\end{array}$ & 72.52 & Licorice straw & This work \\
\hline \multirow[t]{4}{*}{ GUSase } & A. terreus Li-20 & $1.86 a$ & - & Xu Y. et al. \\
\hline & $\begin{array}{l}\text { Streptococcus LJ- } \\
22\end{array}$ & $0.77 a$ & - & Park H. Y. et al. \\
\hline & $\begin{array}{l}\text { P. purpurogenum. } \\
\text { Li-3 }\end{array}$ & $5.90 \times 10^{4} \mathrm{a}$ & - & Zou S. et al. \\
\hline & $\begin{array}{l}\text { C. globosum DX- } \\
\text { THS3 }\end{array}$ & $264.17 \mathrm{~b}$ & Licorice straw & This work \\
\hline \multicolumn{5}{|c|}{ a: GUS proteins were purified and enriched, and enzymatic activities were detected; } \\
\hline \multicolumn{5}{|c|}{ b: GUS activity of solid-state medium was detected. } \\
\hline
\end{tabular}

\subsection{Fructose can significantly improve GAMG production by C. globosum DX-THS3}

Nitrogen and carbon sources play key roles for production of specific products by fermentation using microorganism. Additional nitrogen and carbon sources were added to the licorice straw to further increase the productivity of GAMG by using SSF. First, the nitrogen source was optimized for GAMG production by SSF using $C$. globosum DX-THS3. $\mathrm{NH}_{4} \mathrm{NO}_{3}$, peptone, yeast powder, and yeast extract were used as nitrogen sources for the production of GAMG by C. globosum DX-THS3 (S Fig. 1A). Our results also show that the yield of GAMG was $1.44-(20.21 \mathrm{mg} / \mathrm{g})$ and $1.19-\mathrm{fold}(16.79 \mathrm{mg} / \mathrm{g})$ higher than those of the control $\left(14.02 \mathrm{mg} / \mathrm{g}\right.$ ) when using $\mathrm{NH}_{4} \mathrm{NO}_{3}$ and yeast extract as nitrogen sources after 20 days of fermentation, respectively. The GAMG yields were lower than that of the control when using peptone and yeast powder as nitrogen sources after 20 days of fermentation, with values reaching 13.17 and 13.37 $\mathrm{mg} / \mathrm{g}$, respectively. We further detected the GUS activity after adding $\mathrm{NH}_{4} \mathrm{NO}_{3}$, peptone, yeast powder, and yeast extract as nitrogen sources to the medium. Our results also showed the higher GUS activity when using $\mathrm{NH}_{4} \mathrm{NO}_{3}$ and yeast extract as nitrogen source than the control, whereas those obtained with peptone and yeast powder were lower after 20 days of fermentation (S Fig. 1B). Thus, $\mathrm{NH}_{4} \mathrm{NO}_{3}$ as additional nitrogen source can increase the yield of GAMG by C. globosum DX-THS3 in SSF. Meanwhile, the carbon source for GAMG production was investigated (S Fig. 2). The addition of fructose and glucose can produce 18.38 and $17.12 \mathrm{mg} / \mathrm{g}$ of GAMG after 20 days of fermentation (S Fig. 2A and 2B), respectively, which denoted increases of $33.9 \%$ and $24.7 \%$ than those obtained without a carbon source $(13.73 \mathrm{mg} / \mathrm{g})$. The addition of sucrose can generate $13.98 \mathrm{mg} / \mathrm{g}$ GAMG but showed no significant effect on the production of GAMG using C. globosum DX-THS3 (S Fig. 2C). Our results showed the significant inhibition of GAMG production when adding lactose to the medium for SSF using C. globosum DX-THS3 
after 20 days of fermentation. A total of $9.23 \mathrm{mg} / \mathrm{g}$ GAMG was produced, which was a $34 \%$ reduction in GAMG compared with that obtained without a carbon source (S Fig. 2D). Furthermore, GUS activities with the addition of carbon sources were further detected after 20 days of SSF. Our results showed similarity to those of GAMG production with carbon source (S Fig. 2E). GUS activity with the addition of fructose was $338 \mathrm{U} / \mathrm{g}$, which was significantly higher than that without carbon source $(167 \mathrm{U} / \mathrm{g})$. GUS activity with the addition of glucose was 1.5 -fold $(250 \mathrm{U} / \mathrm{g}$, S Fig. $2 \mathrm{~F})$ higher than that without a carbon source (control, $167 \mathrm{U} / \mathrm{g}$ ). Compared with the control, the addition of sucrose showed no significant effect on GUS activity (155 U/g, S Fig. 2G), but the addition of lactose significantly inhibited GUS activity $(132 \mathrm{U} / \mathrm{g}$, S Fig. $2 \mathrm{H}$ ). Thus, $\mathrm{NH}_{4} \mathrm{NO}_{3}$ and fructose can significantly promote GAMG production of $C$. globosum DXTHS3 by SSF using licorice straw as a medium.

The yield of GAMG during the SSF period with or without carbon and nitrogen sources was detected to further investigate the production of GAMG using C. globosum DX-THS3. First, we detected the yield of GAMG with or without the addition of carbon source (Fig. 4A). The variation trends of GAMG yields were similar. All the test yields of GAMG slowly increased at the initial stage of SSF ( $0-15$ days), whereas those at the middle stage rapidly increased (15-30 days). Then, the yields of GAMG stabilized at about $32 \mathrm{mg} / \mathrm{g}$ at the late stage of SSF (after 30 days). Although all the test yields of GAMG exhibited no significant difference at the later stage of SSF (S Fig. 3), the productivities of GAMG by SSF with different carbon sources or without a carbon source presented significant differences. Compared with the control (33 days), the addition of fructose was the fastest for GAMG production, and 25 days of SSF was used to reach $90 \%$ conversion $(Y=31.52 \mathrm{mg} / \mathrm{g}), 28$ days for the addition of glucose, and 30 days for the addition of sucrose. The addition of lactose to the medium can inhibit GAMG production by $C$. globosum DX-THS3 in SSF, requiring 38 days to reach $90 \%$ conversion. Meanwhile, the addition of nitrogen source also showed significant effect on the production of GAMG by SSF using C. globosum DX-THS3. As shown in Fig. $4 \mathrm{~B}$, compared with that without nitrogen source, the addition of $\mathrm{NH}_{4} \mathrm{NO}_{3}$ to the medium achieved improved production of GAMG by C. globosum DX-THS3, with a reduction of 9 days in the production period to transform $90 \%$ of GL compared with that without a nitrogen source. Yeast extract showed no effect on the production of GAMG, whereas yeast powder and peptone can inhibit GAMG production. Thus, $\mathrm{NH}_{4} \mathrm{NO}_{3}$ and fructose were further optimized. First, different concentrations of $\mathrm{NH}_{4} \mathrm{NO}_{3}$ and fructose $(3,5,7,9$, and $11 \mathrm{mg} / \mathrm{g})$ were added to the SSF medium. Then, GAMG production was detected after 20 days of SSF. Our results show that $7 \mathrm{mg} / \mathrm{g} \mathrm{NH}_{4} \mathrm{NO}_{3}$ and $5 \mathrm{mg} / \mathrm{g}$ fructose were the optimum conditions for GAMG production by C. globosum DX-THS3 using SSF (Fig. 4C and 4D, respectively). Based on the above results, GAMG was produced faster under these optimal conditions than the control: $0.26-0.85 \mathrm{~mm}$ particle size, $28^{\circ} \mathrm{C}, 96 \mathrm{~h}$ seed age, $20 \%$ inoculum size, $1: 3$ solid-liquid ratio, $7 \mathrm{mg} / \mathrm{g}$ $\mathrm{NH}_{4} \mathrm{NO}_{3}$, and $5 \mathrm{mg} / \mathrm{g}$ fructose (Fig. $4 \mathrm{E}$ ). Under these optimal conditions, the percent conversion of $\mathrm{GL}$ reached $90 \%$ within 15 days, whereas the control needed 35 days, that is, an additional 20 days needed for $90 \%$ conversion (Table 1 and Fig. $4 \mathrm{E})$. The productivity of optimization $\left(P=2.1 \mathrm{mg} \cdot \mathrm{g}^{-1} \cdot \mathrm{day}^{-1}\right)$ increased by $133.33 \%$ compared with that in non-optimized conditions $\left(P=0.9 \mathrm{mg} \cdot \mathrm{g}^{-1} \cdot \mathrm{day}^{-1}\right)$. 
Microorganic fermentation can be classified into three stages: early, middle, and late stages. In general, low-cost and easily available substrates, such as crop straw, are usually used as medium for SSF using fungi. However, complex and adequate enzymes are needed for the degradation of polysaccharides in these substrates (Prajapati et al., 2018; Deswal et al., 2011; Pandey, 2003; Nutongkaew et al., 2019; Ezeilo et al., 2019). Compared with liquid fermentation, more time is needed for fungal cell growth to secrete a complex enzyme system in SSF. Thus, fast accumulation of biomass is the key for shortening the early stage period and increasing the productivity of SSF. To reduce this period, we first optimized the fermentation conditions, including the particle size, temperature, seed age, inoculum size. and water content. However, the early stage of GAMG production was long (about 25 days) (Fig. 3B). Thus, several nitrogen sources that are easily utilized by microorganisms were considered. Glucose, fructose, and several monosaccharides (popular carbon sources) can be directly entered into glycolysis and TCA cycle for fungal growth (Fig. 5A). Therefore, we considered adding these carbon sources to the medium to increase productivity when using microorganisms for SSF. Our results demonstrate that the early stage period of SSF was reduced by about 10 days when adding fructose and $\mathrm{NH}_{4} \mathrm{NO}_{3}$ to the medium, thus significantly increasing productivity (Table 1 and Fig. 4E). In this study, lignocellulose and GL of licorice straw were used as carbon sources for $C$. globosum DX-THS3 growth, and high lignocellulose-degrading enzymatic activities were detected during 5-15 days of fermentation (Fig. 3D). High GUS activities were observed at 20-25 days (Fig. 3C), and the concentration of reducing sugar abruptly increased at 20 days of fermentation. These findings demonstrate that lignocellulose was first utilized, followed by $\mathrm{GL}$, by $C$. globosum DX-THS3. Thus, certain carbon sources were added to the medium to reduce the early stage period and increase the GAMG production. In summary, at the initial period of SSF, several lignocellulosedegrading enzymes were secreted because of the rare biomass of $C$. globosum DX-THS3. C. globosum DX-THS3 slowly grew. Thus, a long period was needed for the accumulation of $C$. globosum DX-THS3 to secrete sufficient lignocellulose-degrading enzymes. Subsequently, GUS was rapidly secreted by $C$. globosum DX-THS3 for the utilization of GL as a carbon source to generate GAMG and glucuronic acid (Gur). If several popular carbon sources, such as fructose, are added to medium, C. globosum DX-THS3 will grow fast, which can promote the secretion of lignocellulose-degrading enzymes and fast utilization of lignocellulose, significantly reducing the time for production of GAMG (Fig. 5B). Thus, our study provides a novel, fast, and low-cost method for the production of GAMG.

\section{Conclusions}

In the present study, C. globosum DX-THS3 can use licorice straw as a medium for SSF. After optimization of fermentation conditions, $90 \%$ GL was transformed to GAMG within 15 days, whereas the control needed 35 days. The production of GAMG can reach $2.1 \mathrm{mg} \cdot \mathrm{g}^{-1} \cdot$ day $^{-1}$, which was 2.33 -fold higher than that of the control. Meanwhile, high lignocellulose-degrading enzymatic activities were also detected during SSF. Therefore, our study contributes to the application of SSF in the production of GAMG and strongly demonstrated $C$. globosum DX-THS3 as a potential candidate for producing lignocellulose-degrading enzymes. 


\section{Declarations}

\section{Authors' contributions}

BLG, YWX, QZ, and JRS did the experiments. ZBZ provided resources. DZ and BLG supervised the project, designed the experiments, and wrote the manuscript. All authors read and approved the final manuscript.

\section{Funding}

This work was supported by the Natural Science Foundation of China (31960078), by Foundation of Jiangxi Educational Committee (GJJ190593, GJJ180636), by Funds of Jiangxi Science \& Technology Normal University (2018BSQD028, 2017XJZD004).

\section{Acknowledgements}

Not applicable.

\section{Availability of data and materials}

Not applicable.

\section{Competing interests}

The authors declare that they have no competing interests.

\section{Ethics approval and consent to participate}

Not applicable.

\section{Consent for publication}

All authors have read this article and have approved its submission to Bioresources and Bioprocessing.

\section{References}

1. Akao T (2000) Differences in the metabolism of glycyrrhizin, glycyrrhetic acid and glycyrrhetic acid monoglucuronide by human intestinal flora. Biol Pharm Bull 23(12):1418-1423. https://doi.org/10.1248/bpb.23.1418

2. Amin HA, El-Menoufy HA, El-Mehalawy AA, Mostafa EE (2010) Microbial production of glycyrrhetic acid 3-0-mono- $\beta$-D-glucuronide from glycyrrhizin by Aspergillus terreus. Malay J Microbiol 6:209216. https://doi.org/10.21161/mjm.21509

3. Bailly C, Gérard V (2020) Glycyrrhizin: An alternative drug for the treatment of COVID-19 infection and the associated respiratory syndrome. Pharmacol Therapeut 214:107618.

https://doi.org/10.1016/j.pharmthera.2020.107618 
4. Bahrin EK, Seng PY, Abd-Aziz S (2011) Effect of oil palm empty fruit bunch particle size on cellulase production by Botryosphaeria sp. under solid state fermentation. Aust J Basic Appl Sci 5(3):276-280

5. Brieskorn CH, Lang J (1978) 18ß-glycyrrhetic acids and their sweet flavor. Arch Pharm Bull 311:1001-1009

6. Deswal D, Khasa YP, Kuhad RC (2011) Optimization of cellulose production by a brown rot fungus Fomitopsis sp RCK2010 under solid state fermentation. Bioresour Technol 102(10):6065-6072. https://doi.org/10.1016/j.biortech.2011.03.032

7. Ezeilo UR, Lee CT, Huyop F, Zakaria II, Wahab RA (2019) Raw oil palm frond leaves as cost-effective substrate for cellulase and xylanase productions by Trichoderma asperellum UC1 under solid-state fermentation. J Environ Manage 243:206-217. https://doi.org/10.1016/j.jenvman.2019.04.113

8. Huang YC, Kuo CL, Lu KW, Lin JJ, Yang JL, Wu RS, Wu PP, Chung JG (2016) 18a-glycyrrhetinic acid induces apoptosis of $\mathrm{HL}-60$ human leukemia cells through caspases- and mitochondria-dependent signaling pathways. Molecules 21:872. https://doi.org/10.3390/molecules21070872

9. Ikubar MRM, Abdul Manan M, Md, Salleh M, Yahya A (2018) Solid-state fermentation of oil palm frond petiole for lignin peroxidase and xylanase-rich cocktail production. 3 Biotech 8 (0). https://doi.org/10.1007/s13205-018-1268-1

10. Ito M, Sato A, Hirabayashi K, Tanabe F, Shigeta S, Baba M, De Clercq E, Nakashima H, Yamamoto N (1988) Mechanism of inhibitory effect of glycyrrhizin on replication of human immunodeficiency virus (HIV). Antivir Res 10:289-298. https://doi.org/10.1016/0166-3542(88)90047-2

11. Kalogeris E, Christakopoulos P, Katapodis P, Alexiou A, Vlachou S, Kekos D, Macris BJ (2003) Production and characterization of cellulolytic enzymes from the thermophilic fungus Thermoascus aurantiacus under solid state cultivation of agricultural wastes. Process Biochem 38(7):1099-1104. https://doi.org/10.1016/S0032-9592(02)00242-X

12. Kheng PP, Omar IC (2005) Xylanase production by a fungal isolate, Aspergillus niger USM Al 1 via solid state fermentation using palm kernel cake (PKC) as substrate. Songklanakarin J Sci Technol 27:325-336

13. Kitcha S, Cheirsilp B (2014) Bioconversion of lignocellulosic palm byproducts into enzymes and lipid by newly isolated oleaginous fungi. Biochem Eng J 88:95-100. https://doi.org/10.1016/j.bej.2014.04.006

14. Li B, Yang Y, Chen L, Chen S, Zhang J, Tang W (2017) 18 a-Glycyrrhetinic acid monoglucuronide as an anti-inflammatory agent through suppression of the NF-KB and MAPK signaling pathway. Med Chem Commun 8:1498-1504. https://doi.org/10.1039/C7MD00210F

15. Lin SP, Tsai SY, Hou YC, Chao PDL (2009) Glycyrrhizin and Licorice significantly affect the pharmacokinetics of methotrexate in rats. J Agric Food Chem 57:1854-1859. https://doi.org/10.1021/jf8029918

16. Masuko T, Minami A, Iwasaki N, Majima T, Nishimura SI, Lee YC (2005) Carbohydrate analysis by a phenol-sulfuric acid method in microplate format. Anal Biochem 339(1), 69-72. https://doi.org/ 10.1016/j.ab.2004.12.001 
17. Michaelis M, Geiler J, Naczk P, Sithisarn P, Leutz A, Doerr HW, Cinatl J (2011) Glycyrrhizin exerts antioxidative effects in H5N1 influenza a virus-infected cells and inhibits virus replication and proinflammatory gene expression. PLoS One 6:e19705. https://doi.org/10.1371/journal.pone.0019705

18. Mizutani K, Kuramoto J, Tamura Y, Ohtake N, Doi S, Nakaura M, Osamu T (1994) Sweetness of glycyrrhetic acid 3-0- $\beta$-d-monoglucuronide and the related glycosides. Biosci Biotech Bioch 58, 554555. https://doi.org/ 10.1271/bbb.58.554

19. Murck H (2020) Symptomatic Protective Action of Glycyrrhizin (Licorice) in COVID-19 Infection. Front in Immunol 11, 1239. https://doi.org/ 10.3389/fimmu.2020.01239

20. Natália PM, Pereira JDC, Gomes E, Silva RD, Bocchini DA (2018) Cellulases and xylanases production by endophytic fungi by solid state fermentation using lignocellulosic substrates and enzymatic saccharification of pretreated sugarcane bagasse. Ind Crop Prod 122, 66-75. https://doi.org/ 10.1016/j.indcrop.2018.05.022

21. Nutongkaew T, Prasertsan P, Leamdum $C$, Sattayasamitsathit $S$, Noparat $P$ (2019) Bioconversion of Oil Palm Trunk Residues Hydrolyzed by Enzymes from Newly Isolated Fungi and Use for Ethanol and Acetic Acid Production Under Two-Stage and Simultaneous Fermentation. Waste Biomass Valori, 115. https://doi.org/ 10.1007/s12649-019-00678-x

22. Pandey A (2003) Solid-state fermentation. Biochem Eng J 13(2-3):81-84. https://doi.org/10.1016/S1369-703X(02)00121-3

23. Park HY, Kim NY, Han MJ, Bae EA, Kim DH (2005) Purification and characterization of two novel $\beta$ glucuronidases converting glycyrrhizin to $18 \beta$-glycyrrhetinic acid-3-O- $\beta$-D-glucuronide from Streptococcus LJ-22. J Microbiol Biotechnol 15:792-799

24. Prajapati PB, Suryawanshi KR, Agrawal S, Ghosh M, Kango N (2018) Bioresource Technology Characterization of cellulase from Aspergillus tubingensis NKBP-55 for generation of fermentable sugars from agricultural residues. Bioresour Technol 250:733-740. https://doi.org/10.1016/j.biortech.2017.11.099

25. Raghuwanshi S, Deswal D, Karp M, Kuhad RC (2014) Bioprocessing of enhanced cellulase production from a mutant of Trichoderma asperellum RCK2011 and its application in hydrolysis of cellulose. Fuel 124:183-189. https://doi.org/10.1016/j.fuel.2014.01.107

26. Sherief AA, El-Tanash AB, Atia N (2004) Cellulase production by Aspergillus fumigatus grown on mixed substrate of rice straw and wheat bran. Res J Microbiol 5(3):199-211. https://doi.org/10.3923/jm.2010.199.211

27. Singh V, Haque S, Niwas R, Srivastava A, Pasupuleti M, Tripathi CK (2017) Strategies for fermentation medium optimization: An in-depth review. Front. Microbiol. 7, 2087. https://doi.org/10.3389/fmicb.2016.02087

28. Suryanarayanan TS, Govindarajulu MB, Gopalan V (2012) Fungal endophytes: an untapped source of biocatalysts. Fungal Divers 54(1):19-30. https://doi.org/10.1007/s13225-012-0168-7

29. Wang C, Guo XX, Wang XY, Qi F, Feng SJ, Li C, Zhou XH (2013) Isolation and characterization of three fungi with the potential of transforming glycyrrhizin. World J Microbiol Biotechnol 29(5):781-788. 
https://doi.org/10.1007/s11274-012-1233-9

30. Wang HL, Li YX, Niu YT, Zheng J, Wu J, Shi GJ, Ma L, Niu Y, Sun T, Yu JQ (2015a) Observing antiinflammatory and anti-nociceptive activities of glycyrrhizin through regulating COX-2 and proinflammatory cytokines expressions in mice. Inflammation 38:2269-2278. https://doi.org/10.1007/s10753-015-0212-3

31. Wang Y, Gao BL, Li XX, Zhang ZB, Yan RM, Yang HL, Zhu D (2015b) Phylogenetic diversity of culturable endophytic fungi in Dongxiang wild rice (Oryza rufipogon Griff), detection of polyketide synthase gene and their antagonistic activity analysis. Fungal Biol 119:1032-1045. https://doi.org/10.1016/j.funbio.2015.07.009

32. Xu Y, Feng X, Jia J, Chen X, Jiang T, Rasool A, Lv B, Qu L, Li C (2018) A novel $\beta$-glucuronidase from Talaromyces pinophilus Li-93 precisely hydrolyzes glycyrrhizin into glycyrrhetinic acid 3-0-mono- $\beta$-Dglucuronide. Appl Environ Microbiol 84:e00755-e00718. https://doi.org/10.1128/AEM.00755-18

33. Xu X, Lin M, Zang Q, Shi S (2018) Solid state bioconversion of lignocellulosic residues by Inonotus obliquus for production of cellulolytic enzymes and saccharification. Bioresour Technol 247:88-95. https://doi.org/10.1016/j.biortech.2017.08.192

34. Zhao K, Xue PJ, Gu GY (2008) Study on determination of reducing sugar content using 3,5dinitrosalicylic acid method. Food ence

35. Zhang Q, Gao BL, Xiao YW, Yang HL, Wang Y, Du LQ, Zhu D (2020) Purification and characterization of a novel $\beta$-glucuronidase precisely converts glycyrrhizin to glycyrrhetinic acid 3 - 0 -mono- $\beta$-dglucuronide from plant endophytic Chaetomium globosum DX-THS3. Int J Biological Macromol 159:782-792. https://doi.org/10.1016/j.ijbiomac.2020.05.047

36. Zou S, Liu G, Kaleem I, Li C (2013) Purification and characterization of a highly selective glycyrrhizinhydrolyzing $\beta$-glucuronidase from Penicillium purpurogenum Li-3. Process Biochem 48(2):358-363. https://doi.org/10.1016/j.procbio.2012.12.008

\section{Figures}



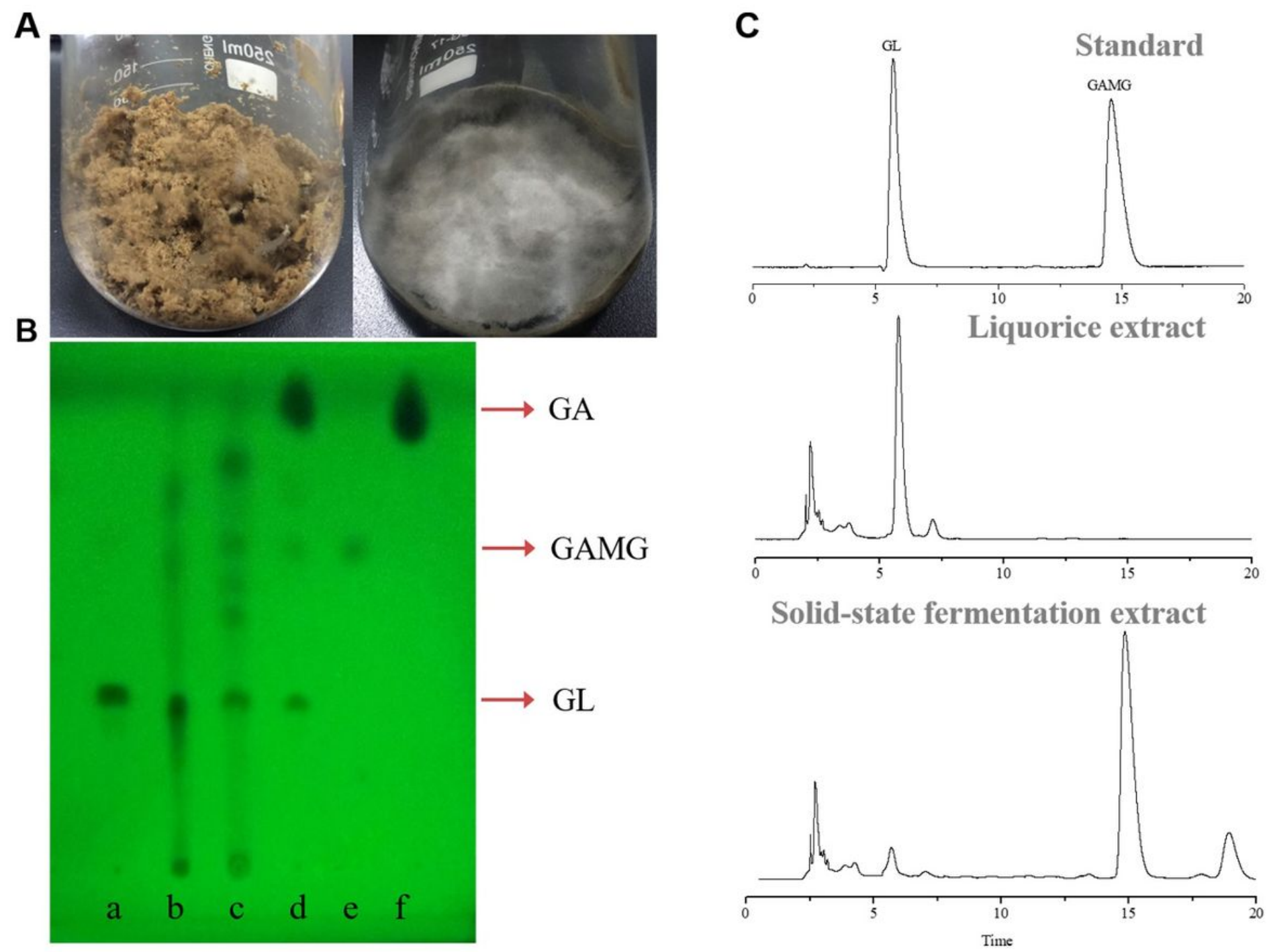

\section{Figure 1}

C. globosum DX-THS3 can grow on licorice straw for GAMG production. Licorice straw was used as a medium for C. globosum DX-THS3 growth (left, A). Depth fermentation was performed after 20 days (right, B), and the product was analyzed by TLC (B) and UPLC analyses. 
A

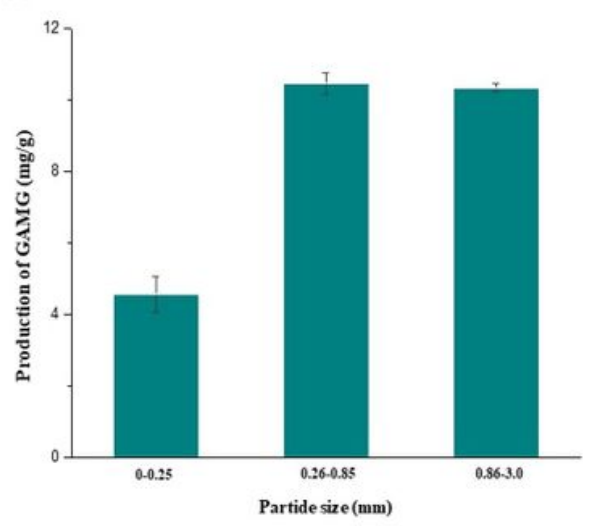

D

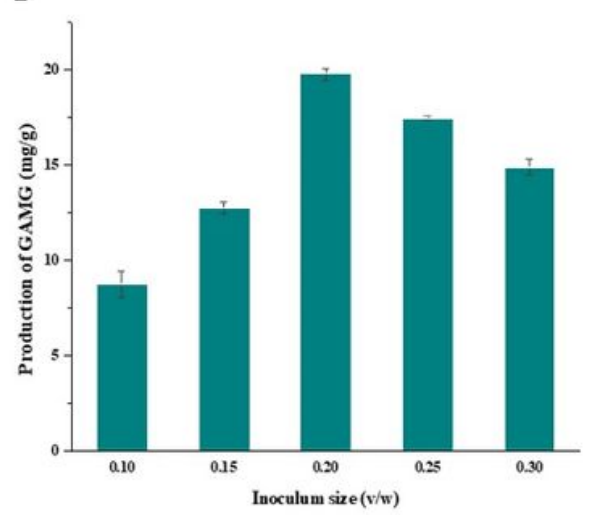

B

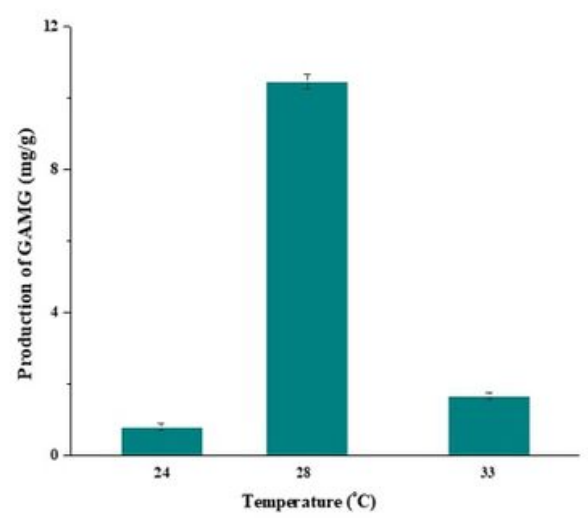

E

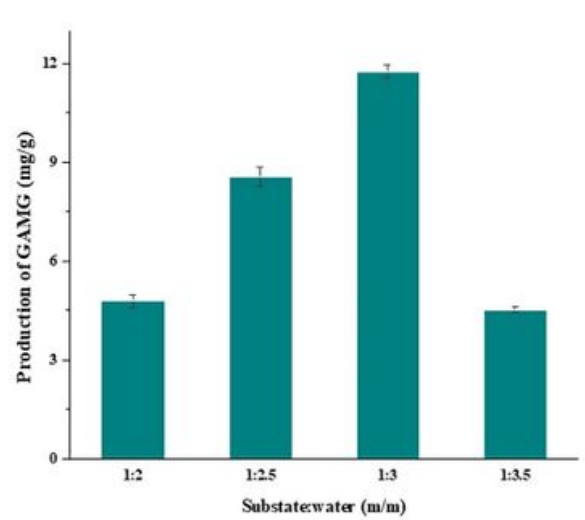

C

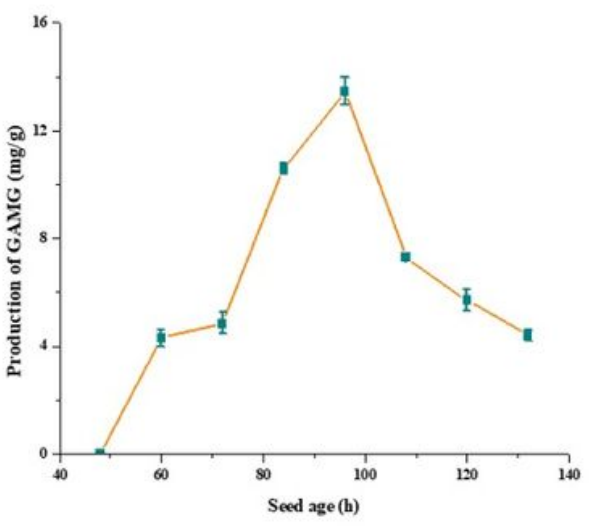

Figure 2

Optimization of fermentation conditions, including particle size (A), temperature (B), seed age (C), inoculum size (D), and substrate:water (E). 
A

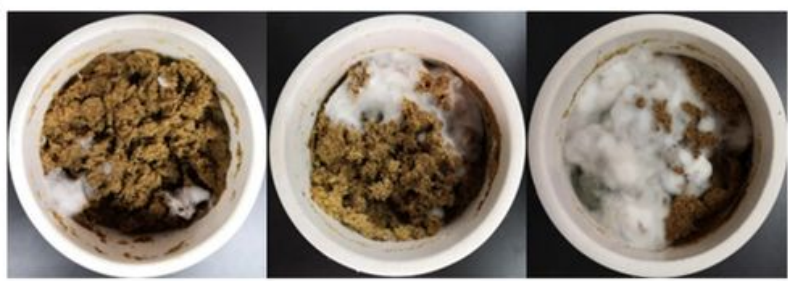

$2 d$

$6 \mathrm{~d}$

$12 \mathrm{~d}$

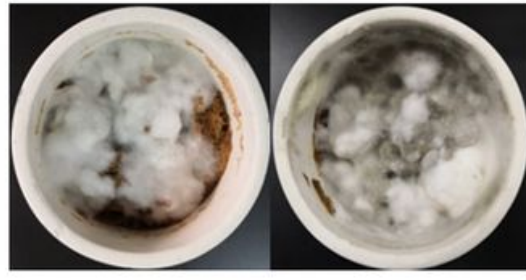

$15 \mathrm{~d}$

B

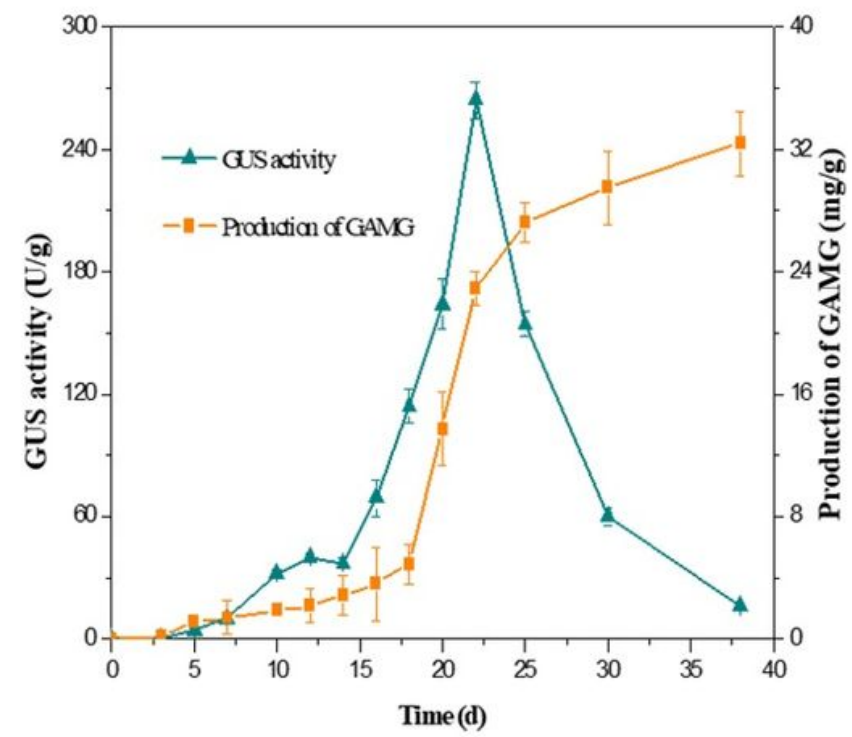

C

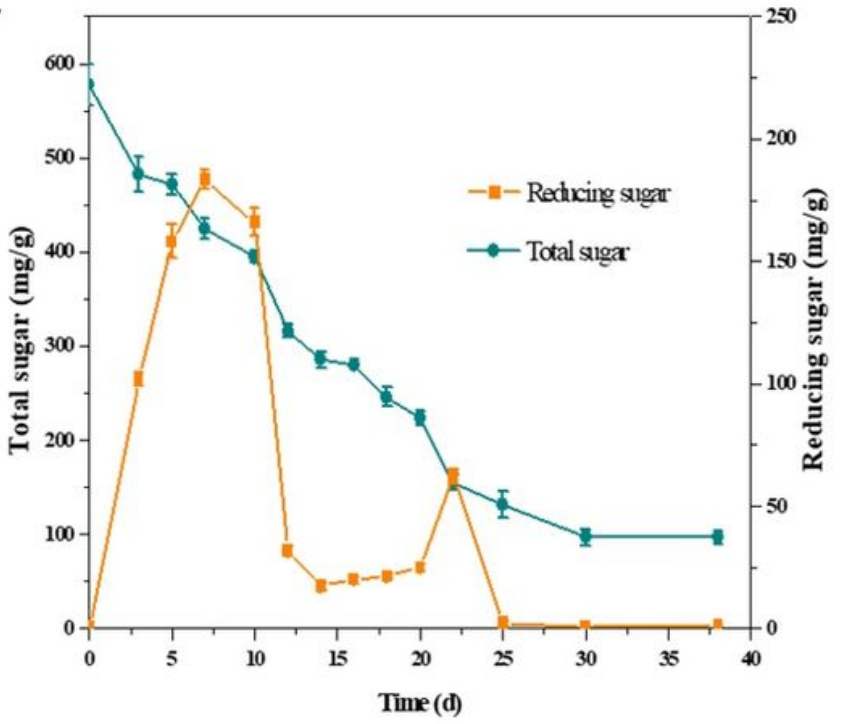

D

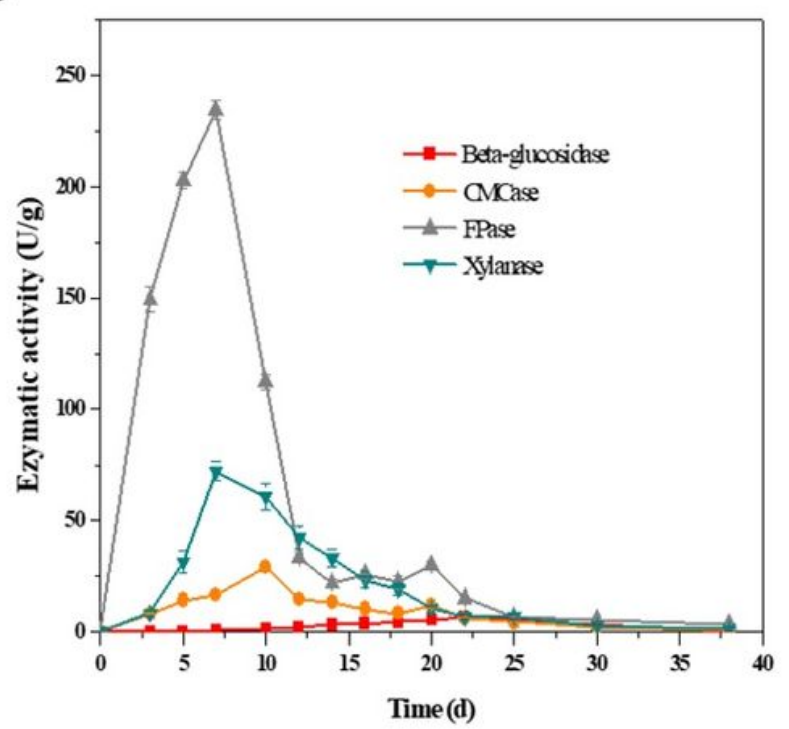

Figure 3

GUS activity, GAMG, reducing sugar, total sugar, and lignocellulose-degrading enzymatic activity profiles of C. globosum DX-THS3 under optimal SSF conditions. (A) C. globosum DX-THS3 was grown on licorice straw for depth fermentation. (B) GUS activity and yield of GAMG profile; (C) reducing sugar and total sugar profile; (D) CMCase, FPase, $\beta$-glucosidase, and xylanase profile. 

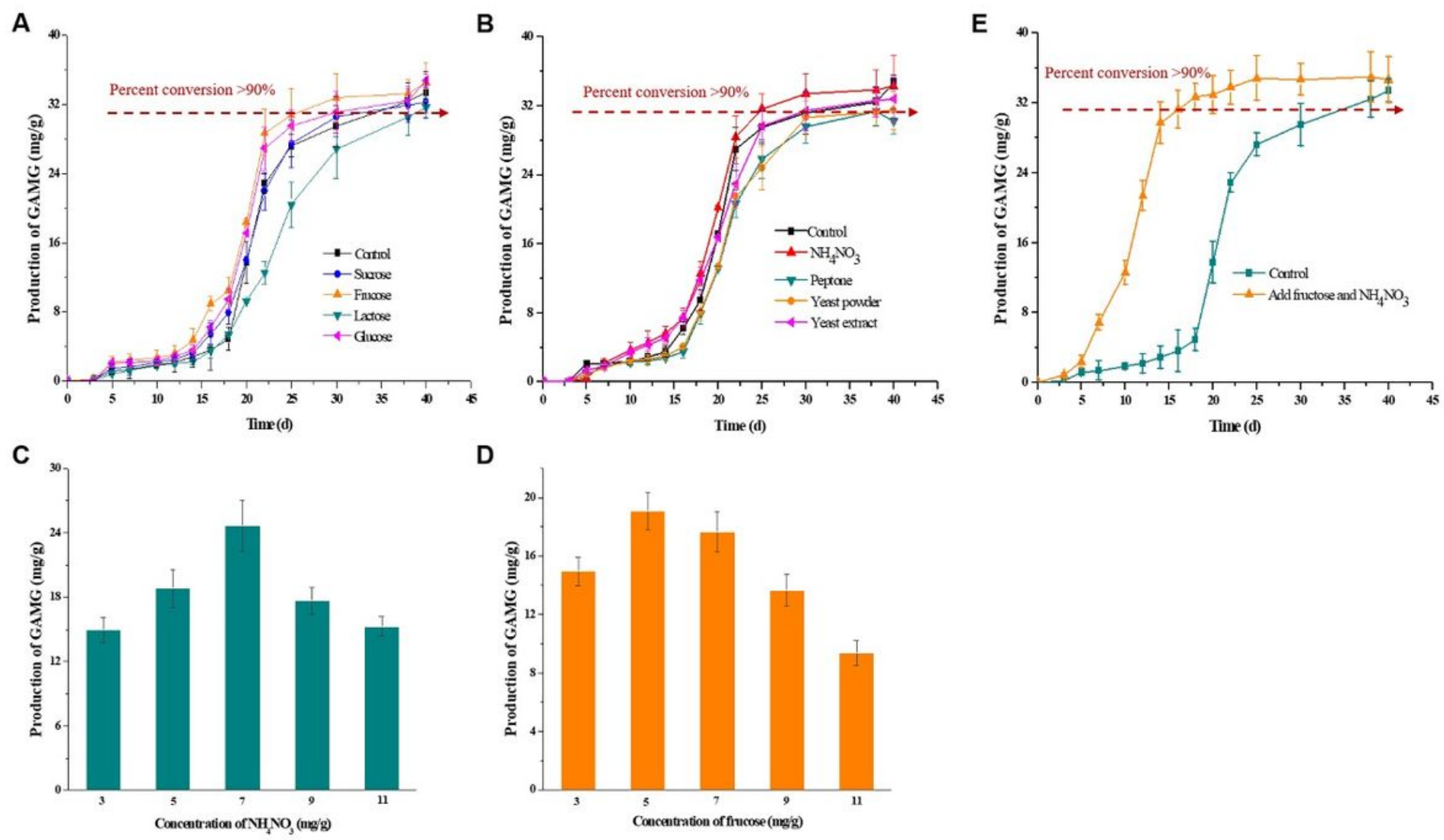

Figure 4

Effect of nitrogen and carbon sources on GAMG production. Yield of GAMG profile with the addition of (A) different nitrogen sources, (B) various carbon sources, (C) different concentration of NH4NO3, (D) different concentration of fructose and $(E)$ under optimal fermentation conditions. 


\section{A}

Popular carbon source

\section{Fructose \\ Glucose}

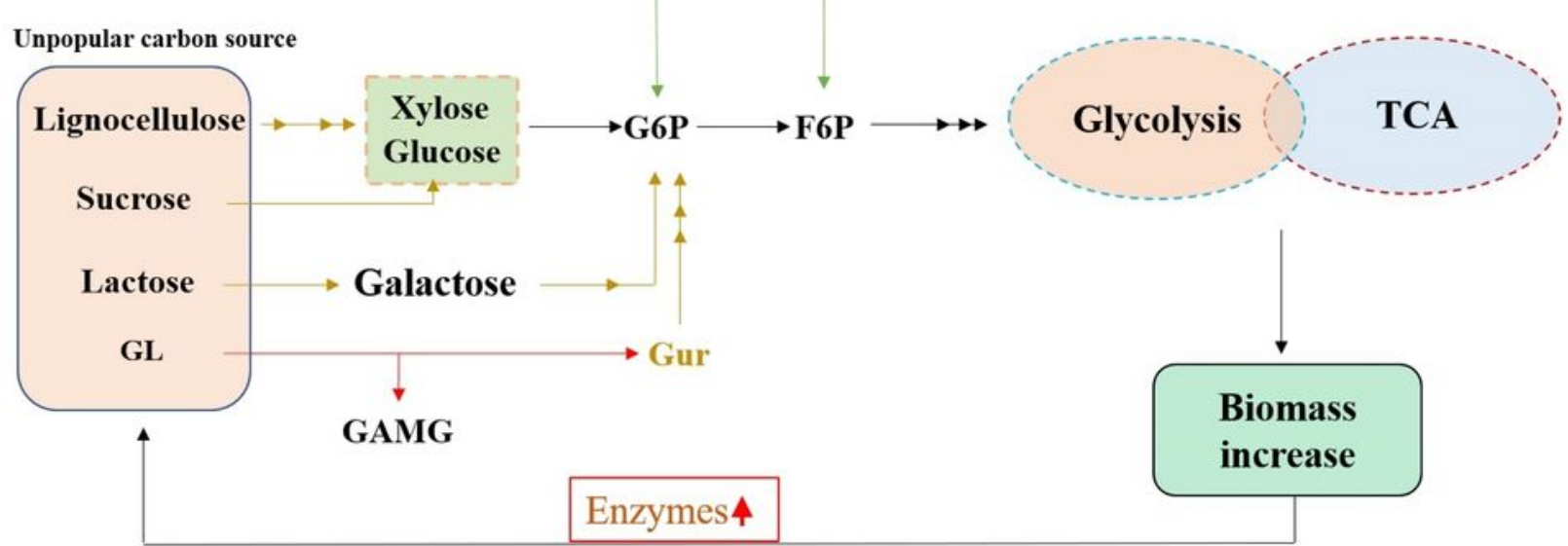

B

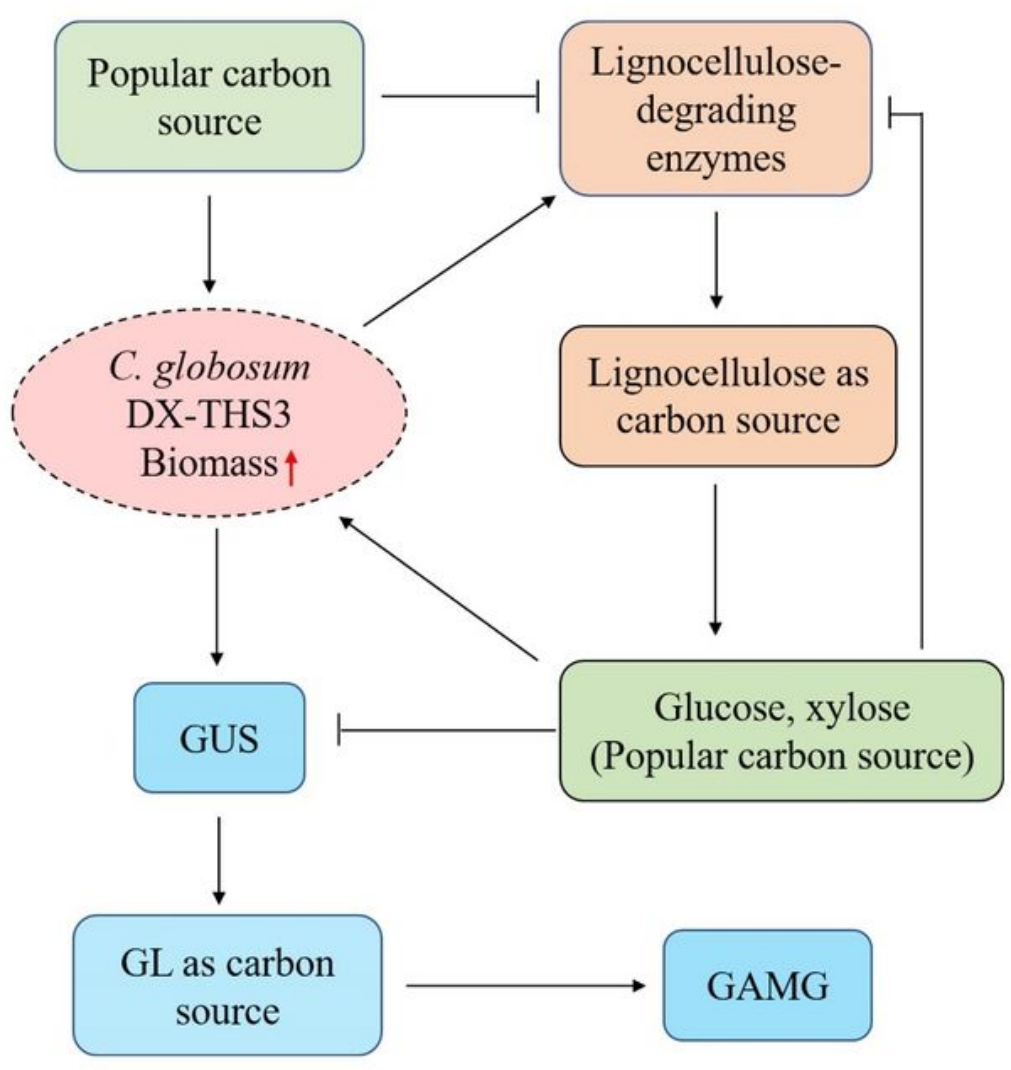

\section{Figure 5}

Predicted mechanism for promoting GAMG production by the addition of fructose to the medium. (A) Fructose and glucose (popular carbon sources) were more rapidly utilized by C. globosum DX-THS3 than lignocellulose, sucrose, lactose, and GL because such popular carbon sources can directly enter glycolysis and TCA cycle. (B) Popular carbon sources can promote the rapid accumulation of C. 
globosum DX-THS3 biomass, producing more lignocellulose-degrading enzymes, rapidly utilizing lignocellulose, and finally fast-transforming GL into GAMG.

\section{Supplementary Files}

This is a list of supplementary files associated with this preprint. Click to download.

- GraphicalAbstract.docx

- Supplement.docx 